\title{
Careers in Horticulture: The Video
}

Where are the students? How can we attract them to horticulture? These questions are not new-we have all asked them many times over the past decade. The answer to the first question is easy. Many of our prospective students are in middle and high schools, colleges, and universities. The answer to the second question is less clear. Three things must come together before we see enrollment of horticulture students rise significantly: 1) a strong industry that promises a future of exciting jobs for skilled workers, 2) solid educational programs that keep students interested and teach them the skills they need to succeed in the industry, and 3) an aggressive recruitment program that lets potential students know that horticulture is a good career choice.

It is no secret that the horticulture industry has a great need for skilled and creative workers. Dorrance (1989), for example, summarized Vermont's need for skilled horticultural workers. Business journals cite horticulture as one of the positive components of the nation's lagging economy (Katz, 1991) and even as one of the "10 careers on the verge" (Morris, 1990). The nation's rising rate of consumption of fresh fruits and vegetables (Dunlop, 1991) and ornamental horticultural crops (Johnson, 1991) suggests a great potential for increased domestic production and creative marketing strategies. The potential in floriculture alone is great. The Society of American Florists (1991) reports that the combined floriculture and ornamental horticulture industries comprise nearly $10 \%$ of crop agriculture and that the United States floriculture industry has grown at a steady rate of $8 \%$ per year for the last several years. The U.S. Secretary of Agriculture, in recognition of this industry's potential, recently created a position (filled by $\mathrm{H}$. Marc Cathey) to investigate the marketing and research needs of the floral and nursery industry.

Our horticulture education programs could benefit from some updating in methodology to keep the attention of the students of the 1990s (Connor, 1989). The transition is well underway, as indicated by a brief review of some of the posters and presentations at the last two ASHS national meetings (Baker, 1990; Biggs et al., 1991; Dana, 1991; Duray and Davies, 1990; Ferguson, 1991; Haque et

Received for publication 3 Feb. 1992. Accepted for publication 27 Mar. 1992.

Front Cover: Scenes from the filming of the ASHS Careers in Hortrculture Video. al., 1990; Hershey, 1990; Hershey, 1991; Midden, 1990; Smalley, 1991; Staub and Braunschweig, 1990; Stearns, 1991; Taylor et al., 1990; White, 1991; Widhalm and Rhodus, 1991). There has been strong support for educational efforts such as these from the working groups in the ASHS Education Division. Our teaching efforts are producing positive results. Our alumni report that we are doing a good job of preparing them for the industry. Trinklein and Wells (1989) surveyed horticulture alumni from the Univ. of Missouri, Columbia, and reported that $82 \%$ of the respondents felt their horticultural education helped them analyze and solve problems and $60 \%$ felt their horticultural education was well balanced between theory and practical learning.

But where are we on recruiting? Swasey (1988) detailed the Univ. of Delaware's procedure for recruiting students into a graduate program in garden administration. Rhodus (1990) reported considerable effort on the part of individual schools using many tools and approaches, but cited no collaborative efforts and no national focus. National ASHS educational forums (Albrecht, 1990; Stack, 1989) and industry publications (Hundley, 1988; Meister, 1989) have addressed the challenge of student recruitment and have suggested the need for a national effort. The challenge of student recruitment is a major priority for all of us, and it is time to work together on behalf of the future of horticulture.

\section{Reaching youth through video}

Our next generation of horticulture students has grown up in a world in which information is disseminated increasingly through visual media and decreasingly through print media. Young people are attracted to visual media. Consider the popularity of MTV, home movie rentals, and the video diversions offered in stores and shopping malls.

Many of the tools we use for teaching are now available through the video medium. A quick check of educational supply catalogs shows that the number of teaching videos has increased dramatically in recent years. The tools we use for recruitment, such as our brochures, posters, and information packets, can all describe and show pictures of horticulture, but video can bring horticulture to life through a medium that young people know well.

Student recruitment videos for horticulture are not new. Several horticulture departments have produced their own recruitment videos and commercial videos are available from several commodity groups. For several years, ASHS has considered producing a video that would introduce potential students to a wide range of horticultural commodities and disciplines, showcase a wide variety of potential careers, and highlight horticulture across the country.

Many things have come together to make this the right time for the ASHS "Careers in Horticulture" video. The Society's interest has grown stronger in view of the declining enrollment of students and the increasing need for trained horticulturists. Money became available for the video through the Society's Venture Fund. Improved video technology has made it possible to produce a professional quality video at a reasonable cost. We were excited about doing the project and were familiar with the work of a professional videographer who was interested and available.

\section{The challenge}

We set out to produce a video that will capture the excitement of horticulture in a way that will appeal to middle and high school students. Our goal is to include a wide range of commodities, a broad sampling of horticulture'smany scientificdisciplines, and many of the current and future career possibilities that horticulture offers.

From the viewpoint of ASHS, the video must be inclusive and accurate. It must communicate that horticulture is a viable career choice in all of our geographical regions, and that there are exciting horticulture jobs in production and marketing, research and development, and education and extension. The video must communicate that horticulture is a good career choice for students with talent, training, and desire.

From theviewpoint of our target audience, the video must be short, flashy, fast-paced, and segmented. It must portray horticulture in a way that competes for the attention of a generation interested in money, sports, and an upscale lifestyle.

\section{Testing of available horticultural videos}

There are a surprising number of horticultural career videos offered by educational programs and professional associations. Each is valuable because those produced by schools generally describe the strengths of the recruiting institutions and those produced by professional associations focus on specific commodities or disciplines. But we need an all-encompassing video to present a complete picture of horticulture.

The videos on the market differ greatly in production style. To assess the effectiveness of existing styles, and to more clearly define the style of the current project, we showed 1$\mathrm{mm}$ clips of three widely available videos to 60 Members at the 1991 ASHS Annual Meeting at Penn State and to 50 growers and college students. Those surveyed preferred a 15 to 20-min format with an "MTV ap-

(Continued on page 486) 


\section{(Continued from inside front cover)}

proach" (hard visual shots connected with strong music background). Several people also gave us valuable suggestions on locations, industries, and careers to consider in our filming schedule.

Two surveys of youth will also impact this video's style. First, the Future Farmers of America conducted focus groups with high school students to gain input toward upgrading their programs and appeal. They found the top three interests of high school students to be sports, earning money, and recreation (including music). Second, we showed students our 1-min film clip survey that was conducted at Penn State. We compared input from fifth-grade vs. 10th-grade students, urban vs. rural locations, and various regions of the country. The comments and suggestions of the students will be taken very seriously and will have an-impact on how our finished product looks.

\section{Limitations and opportunities}

Every project has limitations. The filming possibilities for a horticulture video are almost endless when all the commodities, disciplines, careers, and geographical locations are considered. We obtained enough funds to film in just four to five locations around the country. These locations were determined largely from the suggestions of our Society's Members. Our time span from start of filming to finished product is Aug. 1991 to July 1992, requiring us to juggle locations around the winter season.

We filmed interns at Longwood Gardens (Kennett Square, Pa.) in the summer; Washington apple and grape harvests, Nebraska pumpkins, and Iowa nurseries in the fall; Florida citrus and landscape industries in the winter. We took full advantage of each trip to film additional sites with multiseasonal interest. For example, on our trip to the northwestem United States, we filmed nursery plant tissue culture and a garden center in Washington and a nursery in Oregon. Our Florida trip provides unique footage from Walt Disney World. The footage from our trip to the midwestem United States includes some of the most creative horticulture career possibilities: zoo horticulture in Nebraska, horticultural therapy in Kansas, and greenhouse plug production in Iowa. Tomato and turf production footage was contributed to our project from Oklahoma. We were able to make several short trips around the northeastern United States for additional footage, including cranberry harvest and small-fruit tissue culture in Massachusetts, farmers' markets and horticulture students in Vermont, landscape architecture and computerized instruction in Pennsylvania, interiorscaping and park horticulture in New York City, potato production in upstate New York, and seed production and handling in Maine.

We would like to thank all the ASHS Members who suggested filming locations and all the local horticulture industry members who went out of their way to help in this project. The enthusiastic cooperation we received has been tremendous and the video could not be done without it.

\section{What is required for a quality video?}

Video production has become much easier in recent years with the introduction of "user friendly" equipment. The resources needed to make a quality video, however, exceeds high-tech equipment. In addition to a solid idea, a supportive granting agency, and the help of countless horticulturists in both industry and education, this project required dedication and commitment.

\section{Cooperators}

We gratefully acknowledge the efforts of Ellen Paparozzi, Univ. of Nebraska, who provided input on the design of the project and coordinated the midwestem film trip and input from the ASHS Educational Media Committee. The project was also greatly enhanced by the expertise of Bob Logsdon, Iris Multimedia, Burlington, Vt., who specializes in agricultural education video production. Leonard Perry and Logsdon have been involved in every filming and either Paparozzi or Lois Berg Stack were involved in all other major trips.

\section{Time required}

The time input required for such a project is remarkable. Consider an average filming day: two locations of $3 \mathrm{~h}$ each, with two to three interviews per location, plus various cover shots, plus $4 \mathrm{~h}$ driving time. For filming alone, three people $\times 10 \mathrm{~h}$ per day $\times 38$ filming and travel days $=1140 \mathrm{~h}$. We estimate that this time can be doubled when accounting for project planning and coordination, film episode preplanning, and postfilming production. That accounts for a conservative estimate of $2280 \mathrm{~h}$ (57 work weeks) and does not include any estimate of the time spent by ASHS Members who contributed ideas, onsite contacts who helped coordinate filming, or those horticulturists who were interviewed and filmed.

\section{Equipment required}

Each trip required $-150 \mathrm{lb}$ of filming equipment. We used a Betacam SP camera compatible with broadcast-quality tape required for making 1/2-inch tapes for distribution to potential students and schools and 3/4-inch tapes for broadcasting on television. We used a high-quality recording deck and monitor. Our lavaliere microphones were able to pick up voices clearly while avoiding wind and other background noise. A remote microphone enabled us to film distant shots, such as an arborist pruning a tree from a bucket. We also carried lights, 4- to 6-h battery packs and rechargers, a tripod, and 60 yards of cords. We generally used a minivan for ground transportation and flew to some locations.

Most of the filming is now completed and our ratio of footage : finished product is » 80:1. For comparison, a 50:1 ratio is typical in the film industry. We are now editing our footage in preparation for the master edit, a process that costs $\$ 250 / \mathrm{h}$, with a ratio of $1 \mathrm{~h}$ master edit : 1 min finished product. It is well worth the expense, as master editing provides special effects like split screens, dissolves, and multiple speech and music tracks.

\section{How does it look?}

Horticulture has something for everyone! The footage shows flowers, fruits, and vegetables, but it also shows other crops (e.g. bonsai and topiary, native plant materials, hops, herbs, and cut flowers); equipment (e.g., fork lifts, tree buckets, tree spades, pear canning, apple fresh pack, and watering booms); technology (e.g., tissue culture, molecular genetics research, automated fruit grading, and automated plant production with robotic booms and conveyers); computers (e.g., computer-assisted landscape design, business management and inventory control, and greenhouse environmental control systems); art (e.g., landscape and floral design); and related disciplines (e.g., entomology, engineering, and plant pathology).

Horticulture is portrayed as research, production, and marketing, but alternative career opportunities are also highlighted: horticultural therapy, community garden management, zoo horticulture, and botanical garden and park management.

We are not certain how young students will perceive horticulture, but we have a good idea from the youngworkers we interviewed. When we asked, "Why have you chosen horticulture as a career?' young workers answered that they make enough money to support their lifestyles, but they chose horticulture primarily because it provides independence on the job, a healthy environment, good physical activity, an opportunity to be outdoors, diversity of tasks, creativity, constant challenge, and fun. Their answers will be an inspiration for us all. Consider the woman working at the Omaha Zoo, which contains the world's largest enclosed rain forest. She enjoys her job because she has the opportunity not only to work in horticulture, but also to educate people about the need to protect wildlife and the environment. Or consider the man who learned horticulture from his grandfather in the Philippines and dreamed of working $\ln$ the United States. Now he works in the Battery Park section of New York City and he speaks to us in the video with the Statue of Liberty in the background.

\section{Marketing "Careers in Horticulture"}

The video will be finished by July 1992 . The national premier will be at the ASHS Annual Meeting in Honolulu and the interna- 
tional premier at the ISHS First International Conference on Education and Training in Horticulture in Auchincruive, Scotland. These premiers will mark the beginning of the marketing process. Our hope is that the video will be made available to every middle and high school in the country at the lowest possible price.. It is important to reach middle school children, since our discussions with educators indicate that children make directional career decisions beginning in the fifth grade.

Christine Radiske, ASHS' public relations director, is developing a marketing plan for the video. She plans to distribute the video with printed material so that young students can share their excitement about horticulture with their parents through take-home literature. We look forward to her efforts that will help us educate both students and parents on what horticulture is all about.

We hope that the young people who view the ASHS "Careers in Horticulture" video will be as impressed as we are with American horticulture.

\section{Literature Cited}

Albrecht, M.L. 1990. Mainstreaming horticulture into public education. ASHS 1990 Annu. Mtg., Tucson, Ariz., Prog. \& Abstr. p. 1042.

Baker, C.L. 1990. Bridging the gap: Education to employment. ASHS 1990 Annu. Mtg., Tucson, Ariz., Prog. \& Abstr. p. 1126.

Biggs, M.S., T.D. Sydnor, and N.L. McCaslin 1991. Computer-videodisc enhancement of plant identification. ASHS 1991 Annu. Mtg., University Park, Pa., Prog. \& Abstr. p. 787.

Connor, L.J. 1989. Land-grant undergraduate ag programs: They need revitalizing. Choices Univ. of Minnesota, Minneapolis-St. Paul. p. 12-15.

Dana, M.N. 1991. "Native Plants of Indiana": Videos for instruction and extension. ASHS 1991 Annu. Mtg., University Park, Pa., Prog. \& Abstr. p. 787-788.
Dorrance, A. 1989. Vermont employment opportunities in horticulture. Vermont Agr. Dept. Montpelier.

Dunlop, G.S. 1991. Public policy issues that challenge the fresh fruit and vegetable industry for 1992. U.S. Dept. Agr. Annu. Agr. Outlook Conf. Dec. 1991. Booklet 63-8.

Duray, S.A. and F.T. Davies, Jr. 1990. A classroom laboratory exercise to demonstrate seed priming. ASHS 1990 Annu. Mtg., Tucson, Ariz., Prog \& Abstr. p. 1111.

Ferguson, J.J. 1991. Incorporation of agricultural databases and software into citriculture courses. ASHS 1991 Annu. Mtg., University Park, Pa., Prog. \& Abstr. p. 787:

Haaue. M., R. Baumgardner, and D. Price. 1990 'Computer-aided design and video-disc technology in landscape design classes. ASHS 1990 Annu. Mtg., Tucson, Ariz., Prog. \& Abstr. p. 1181.

Hershey, D.R. 1990. Sources of plant humor for use in horticultural education. ASHS 1990 Annu. Mtg., Tucson, Ariz., Prog. \& Abstr. p. 1115.

Hershey, D.R. 1991. An inexpensive teaching laboratory exercise to induce carbon dioxide deficiency in plants. ASHS 1991 Annu. Mtg., University Park, Pa., Prog. \& Abstr. p. 725.

Hundley, M. 1988. Horticulture education: The aood news. SAF: Business news for the flora industry. Soc. Amer. Florists 5(9):29-30, 32, 34-35.

Johnson, D.C. 1991. 1992 Floriculture and environment horticulture outlook. U.S. Dept. Agr Annu. Agr. Outlook Conf. Dec. 1991. Booklet 6:14-24.

Katz, H. 1991. Business report: Miami. Profiles 4(12):16.

Meister, R.T. 1989. A symbol: The rickety research greenhouse. Amer. Veg. Grower 37(3):94.

Midden, K.S. 1990. Developing environmental awareness with young people. ASHS 1990 Annu. Mtg., Tucson, Arix., Prog. \& Abstr. p. 1126.

Morris, M. 1990. 15 Fast-track careers. Money 19(6):108-111, 113-114, 116, 118, 121-122, $124,126$.
Rhodus, W.T. 1990. Analysis of recent enrollment trends and recruiting strategies in horticulture. HortScience 25:1443-1446.

Smalley, T.J. 1991. Teaching landscape construction skills to university students. ASHS 1991 Annu. Mtg., University Park, Pa., Prog. \& Abstr. p. 787.

Society of American Florists. 1991. The answer... the floral industry. (Brochure)

Stack, L.B. 1989. Recruiting floriculture students: A strategy for the future. ASHS 1989 Annu. Mtg., Tulsa, Okla., Prog. \& Abstr. p. 20.

Staub, J.E. and K. Braunschweig. 1990. Mutation, a microcomputer module designed for plant breeding and genetics. ASHS 1990 Annu. Mtg., Tucson, Ariz., Prog. \& Abstr. p. 1106.

Stearns, D.T. 1991. Bringing video imaging to the university classroom. ASHS 1991 Annu. Mtg., University Park, Pa., Prog. \& Abstr. p. 793794.

Swasey, J. 1988. Promotion and marketing of horticultural programs. ASHS Northeast Region Annu. Mtg., Orono, Maine.

Taylor, K.H.S., G. Cobb, and J. Zajicek. 1990. A hypercard application for the selection of southern landscape plants. ASHS 1990 Annu. Mtg., Tucson, Ariz., Prog. \& Abstr. p. 1111.

Trinklein, D.H. and J.A. Wells. 1989. Involving alumni in curriculum evaluation. HortScience $24 ; 425-426$

White, J.W. 1991. Interactive computer/videodisc instruction. HortScience 26(6):650.

Widhalm, L. and W.T. Rhodus. 1991. Developing multimedia educational software. ASHS 1991 Annu. Mtg., University Park, Pa., Prog. \& Abstr. p. 726 .

LOIS Berg STACK Dept. of Plant, Soil, and Environmental Sciences Univ. of Maine Orono, ME 04469

and

Leonard P. Perry

Dept. of Plant and Soil Science. Univ. of Vermont Burlington, VT 05405 